\title{
New data on the mammalian systematics and biostratigraphy of the middle Miocene from Húmera (Pozuelo de Alarcón, Madrid)
}

\author{
Juan A. CÁRDABA ${ }^{1 *}$, María PRESUMIDO ${ }^{1}$, Omid FESHARAKI², Ana I. CASADO², Rubén \\ PERALES ${ }^{2}$ \& Marta MUÑIZ PEREZ ${ }^{1}$
}

\begin{abstract}
${ }^{1}$ Geosfera C.B. Departamento de Innovación, Desarrollo e Investigación. C/ Madres de la Plaza de Mayo, Nº 2 , 28523 RivasVaciamadrid, Madrid, Spain; juan@proyectogeosfera.es; maria@proyectogeosfera.es; martampster@gmail.com

${ }^{2}$ Departamento de Paleontología, Universidad Complutense de Madrid, C/ José Antonio Novais 2, 28040 Madrid, Spain; omidfesharaki@hotmail.com; acasadogomez@ucm.es; ruben.perales@gmail.com

* Corresponding author
\end{abstract}

Cárdaba, J.A., Presumido, M., Fesharaki, O., Casado, A.I., Perales, R. \& Muñiz Perez, M. 2013. New data on the mammalian systematics and biostratigraphy of the middle Miocene from Húmera (Pozuelo de Alarcón, Madrid). [Nuevos datos sobre la sistemática y bioestratigrafía de los mamíferos del Mioceno medio de Húmera (Pozuelo de Alarcón, Madrid)]. Spanish Journal of Palaeontology, 28 (1), 29-42.

Manuscript received 16 April 2012

Manuscript accepted 8 January 2013

(C) Sociedad Española de Paleontología ISSN 2255-0550

\begin{abstract}
Thanks to the new micromammal fossil material obtained during the 2010 and 2011 field campaigns from the palaeontological site at Húmera (Madrid Basin, central Spain), we have been able to revise the taxonomic arrangement and increase the number of micromammal taxa recorded and described by Menéndez Gamella et al. (2010). During the last campaigns 182 identifiable remains were recovered, in various states of preservation, belonging to 10 different species of micromammals: Megacricetodon collongensisgersii, Democricetodon larteti, Armantomys tricristatus, Microdyromys aff. monspeliensis, Microdyromys koenigswaldi, Heteroxerus rubricati, Heteroxerus grivensis, Heteroxerus sp., Lagopsis sp. and Galerix sp. This fossil association is correlated with biozone $\mathrm{E}$ (MN5), and provides new information in relation to the end of the Middle Aragonian from the Madrid basin.
\end{abstract}

Keywords: Megacricetodon collongensis-gersii, Democricetodon larteti, biostratigraphy, micromammal, Middle Aragonian.

\section{RESUMEN}

Gracias al nuevo material de micromamíferos fósiles obtenidos durante las campañas de excavación de 2010 y 2011 en el yacimiento paleontológico de Húmera (Cuenca de Madrid, centro de España), hemos sido capaces de precisar la asignación taxonómica y aumentar el número de taxones de micromamíferos registrados, respecto al trabajo de Menéndez Gamella et al. (2010). Durante las últimas campañas se han obtenido 182 restos identificables, en diversos estados de conservación, y han sido asignados a 10 especies diferentes de micromamíferos: Megacricetodon collongensis-gersii, Democricetodon larteti, Armantomys tricristatus, Microdyromys aff. monspeliensis, Microdyromys koenigswaldi, Heteroxerus rubricati, Heteroxerus grivensis, Heteroxerus sp., Lagopsis sp. y Galerix sp. Esta asociación fósil se correlaciona con la biozona $\mathrm{E}$ (MN5), y proporciona nueva información relativa al final del Aragoniense Medio de la Cuenca de Madrid.

Palabras clave: Megacricetodon collongensis-gersii, Democricetodon larteti, bioestratigrafía, micromamífero, Aragoniense Medio. 


\section{INTRODUCTION}

The Madrid Basin is an intracratonic Cenozoic basin, bounded on its three sides by mountain ranges: the Spanish Central System to the west and north, the Iberian and Altomira ranges to the east, and the Toledo mountains to the south. The Central System is a pop-up structure (De Vicente et al., 2007) that was rejuvenated during the Alpine Orogeny (Miocene), and is the main source area for the sediments that form the west edge of the Madrid Basin. The basement of the Madrid Basin was filled mainly with tertiary sediments, predominantly those of Palaeogene age in depth and Neogene age (mainly Miocene) to the surface (Alonso-Zarza et al., 2004). This basin contains many Neogene palaeontological deposits with fossil vertebrate remains that facilitate dating sedimentary formations and their correlation with other basins (Alberdi et al., 1984; Soria et al., 2000; PeláezCampomanes et al., 2003; Hernández-Ballarín et al., 2011). Furthermore, these palaeontological sites provide important palaeoenvironmental and palaeoclimatic information about this particular time period, especially for the Miocene period (Daams \& Van Der Meulen, 1984; Calvo et al., 1993; Hernández Fernández et al., 2006; Domingo et al., 2009, 2012).

The Húmera site is located to the East side of the City of Madrid (Fig. 1), close to the Somosaguas palaeontological site (López-Martínez et al., 2000), allowing thus comparison between both sites and expanding the existing data about the palaeontology of this area of the Madrid basin.

From a geological point of view, the Húmera site is located on the so called "pasillo lutítico de Majadahonda" (Torres et al., 1995), and its principal source area is the Guadarrama mountains to the East side (Menéndez Gamella et al., 2010); it belongs to the Miocene Intermediate Unit (Megías et al., 1983).

From a stratigraphic point of view, two sections (North Húmera and West Húmera) have been studied. These stratigraphic sections are spaced approximately 40 meters from each other, and are very similar in their stratigraphic features and petrological characteristics. The sedimentary succession of both sections is mainly composed of siliciclastic sediments with evidence of precipitation and neoformation of clays and carbonates (calcretes). It shows five different stratigraphic units with their corresponding levels (Menéndez Gamella et $a l ., 2010)$. These units were distinguished according to their sedimentological, petrological and palaeontological characteristics by Menéndez Gamella et al. (2010). From the base to the top of the succession: $\mathrm{H} 1$ and $\mathrm{H} 2$ are sandy units containing macromammal remains with very different states of preservation, and displaying an erosive contact with lag deposits between them; $\mathrm{H} 3$ and $\mathrm{H} 4$ are siltyclayey units separated by a calcrete level, however only H3

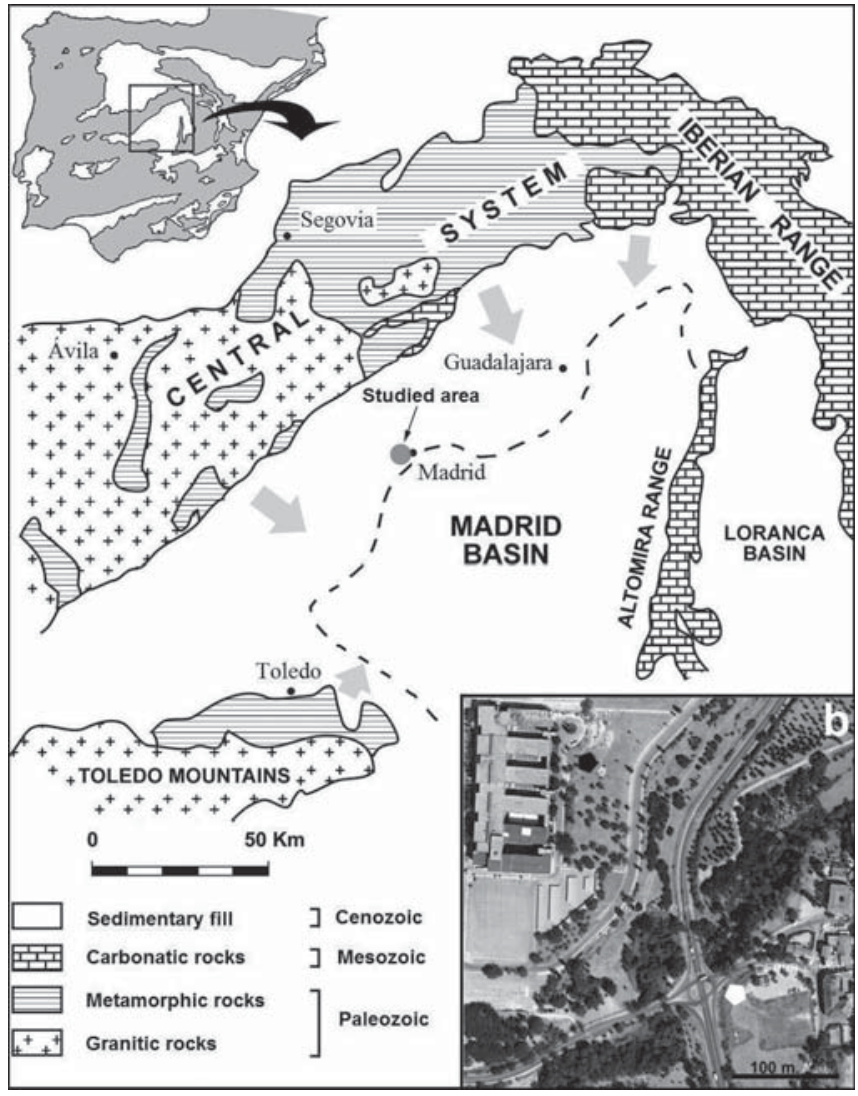

Figure 1. Location and geological maps of the Húmera palaeontological site.

unit contains micromammal fossil remains, which display characteristic taphonomic features; and, finally, H5 unit is an amalgamated unit with mixed characteristics between the $\mathrm{H} 4$ unit and the edaphic horizon. The total thickness of the succession is 3.60 meters. For these five units that form the Húmera stratigraphic sequence, Menéndez Gamella et al. (2010) defined a palaeoenvironment of medium-distal alluvial fans (H1-H2) and ephemeral ponds (H3-H4).

The aim of this paper is to describe systematically the species found in the Húmera palaeontological site, expanding and improving the data provided by Menéndez Gamella et al. (2010) about the faunal association and the biostratigraphy.

\section{MATERIALS AND METHODS}

The studied micromammal remains have been retrieved from sediments collected in $\mathrm{H} 3$ level, during the field campaigns carried out on 2010 and 2011. These materials allow us to complete the results, described by Menéndez Gamella et al. (2010) for the 2009 campaign. Some 900 $\mathrm{kg}$ of sediments from Húmera were screened, of which $830 \mathrm{~kg}$ belong to the last two campaigns. In this paper we 


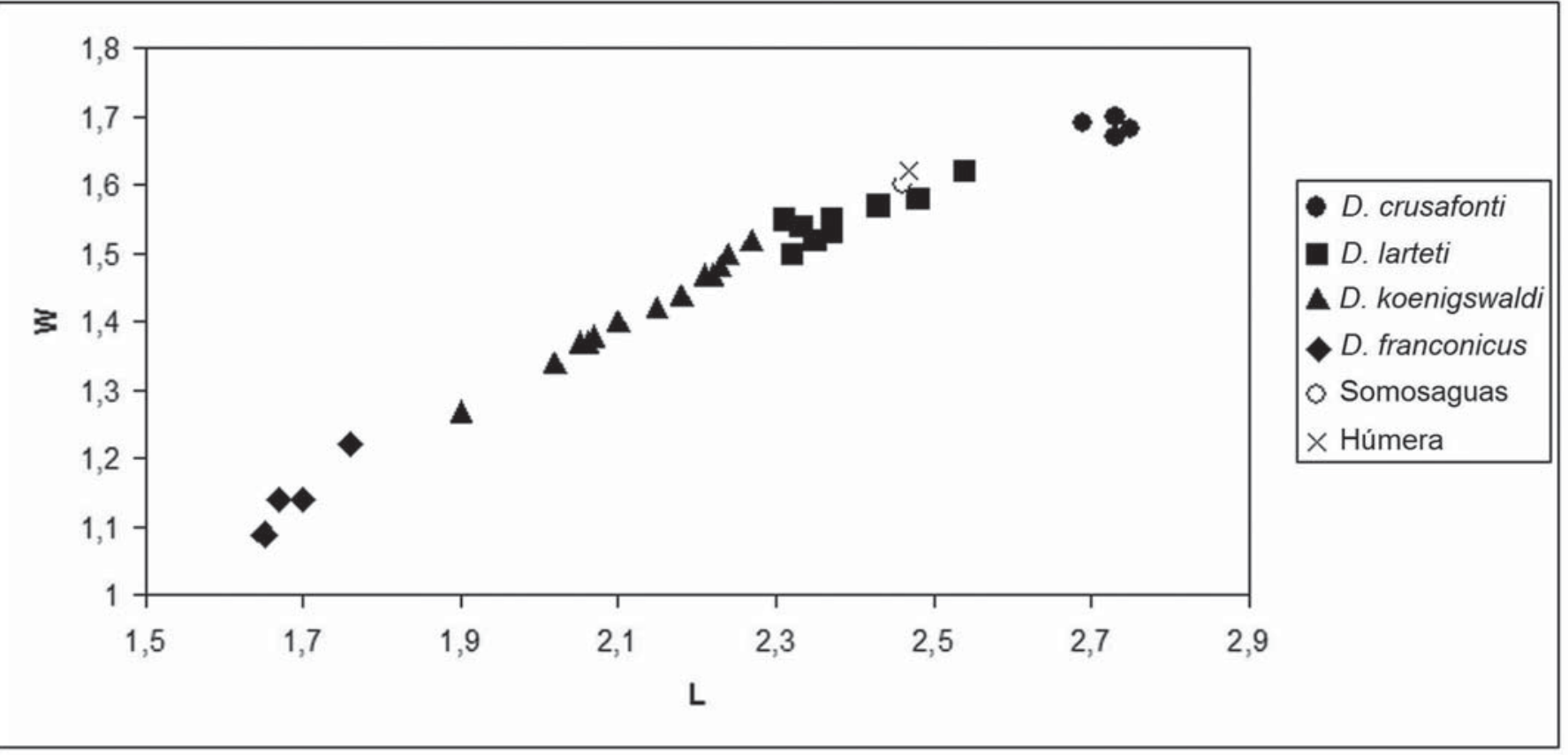

Figure 2. Length/Width (averages) of the first upper molars of Democricetodon franconicus-crusafonti lineage from CalatayudDaroca Basin, including specimens form of Húmera and Somosaguas (Democricetodn larteti).

are describing 182 cheek teeth, which have been added to the results given by Menéndez Gamella et al. (2010). The nomenclature of these for the Cricetidae is after Freudenthal et al. (1994), for the Gliridae after Daams (1981), for the Sciuridae after Cuenca-Bescós (1988), for the Lagomorpha after López-Martínez (1989) and for the Insectivora after Van den Hoek Ostende (2003). The teeth were measured using a $20 \mathrm{x}-40 \mathrm{x}$ binocular microscope and a micrometer. The tables include revised measurements by Menéndez Gamella et al. (2010). The specimens are stored in the National Museum of Natural Sciences from Madrid (MNCN).

\section{SYSTEMATIC PALAEONTOLOGY}

Phylum CHORDATA Bateson, 1885

Class MAMMALIA Linnaeus, 1758

Order RODENTIA Bowdich, 1821

Family Cricetidae Fischer von Waldheim, 1817

Genus Megacricetodon Fahlbusch, 1964

Megacricetodon collongensis-gersii (sensu Hernández-Ballarín et al., 2011)

(Figs 3g-3j)

Material. $5 \mathrm{M} 1,7 \mathrm{M} 2,5 \mathrm{M} 3,6 \mathrm{~m} 1,8 \mathrm{~m} 2$ and $7 \mathrm{~m} 3$.
M1: The anterocone is deeply split. The labial anterocone is the most developed. None of the specimens present labial spur of the anterolophule. Two out of 3 specimens have a well-developed ectoloph, whereas the other one has a short protuberance. The mesoloph is short in all specimens. None of the specimens have the ectoloph connected to the mesoloph. Sinus is transverse in 3 out of 4 , being it is slightly curved forward in other one. The metalophule is connected to the posteroloph just behind the hypocone.

M2: The protolophule points obliquely forward, and it is connected to the anterolophule in front of the protocone. The ectoloph is a short protuberance in 6 out of 7 , and it is absent in other one. The mesoloph is long in 2, medium in 2 , and short in 3 specimens. Only two specimens have the ectoloph connected to the mesoloph. Sinus is transverse in 6 out of 7, whereas it is slightly curved forward in other one. The metalophule is transverse and connected to the hypocone in 1 out of 7 specimens, it is connected to the entoloph, in front of the hypocone, in 4 out of 7 ; the remaining specimens have an oblique metalophule, reducing the posterosinus to a small valley.

M3: The labial anterolophule is well developed in all specimens, unlike the lingual. The paracone is the most developed cusp, followed by the protocone, whereas the hypocone is the smallest. The protolophule is inserted into the front of the protocone, and the metalophule connects to the front of the hypocone. The posteroloph is well developed.

Measurements. Table 1. 

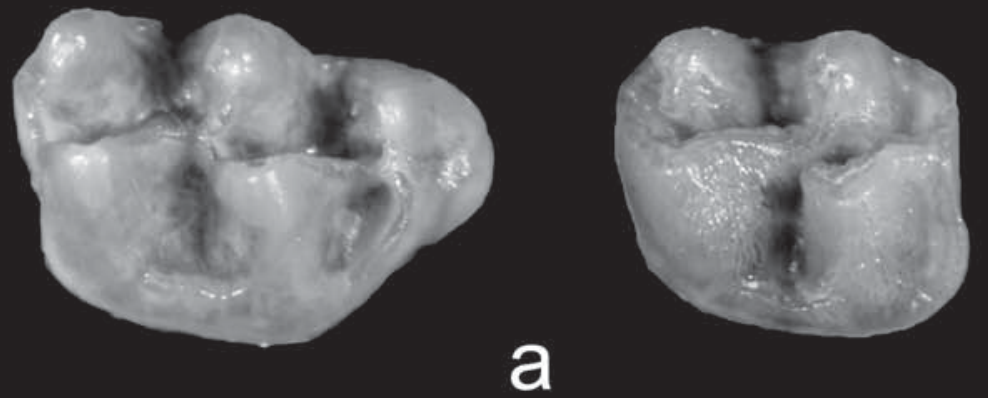

a

b
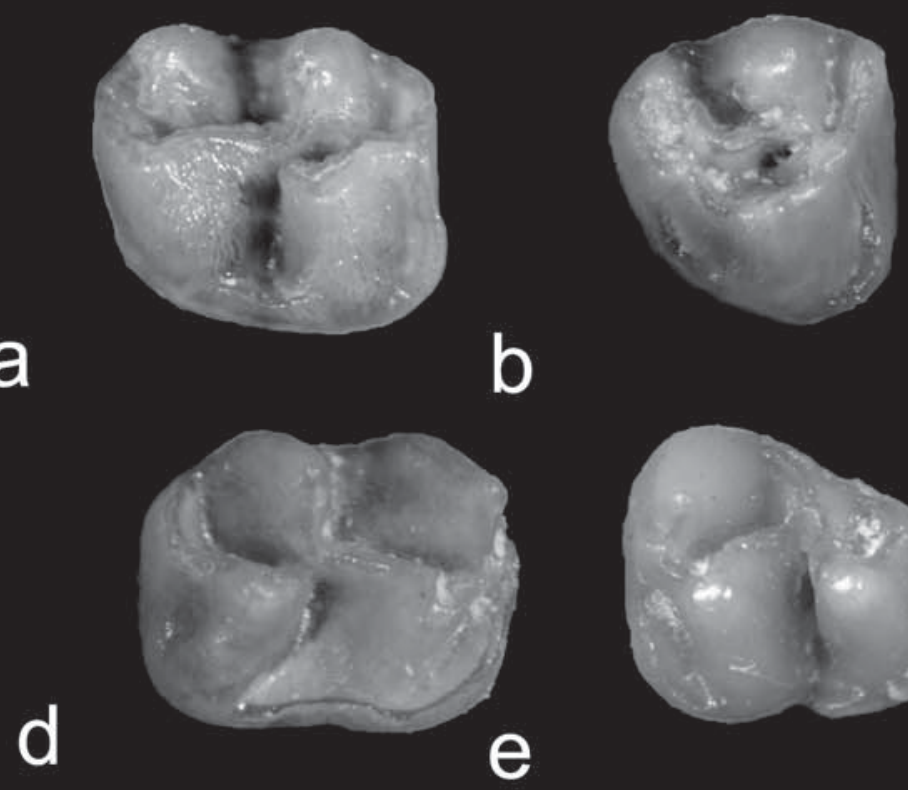

C

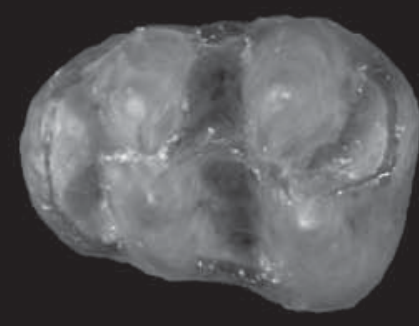

e
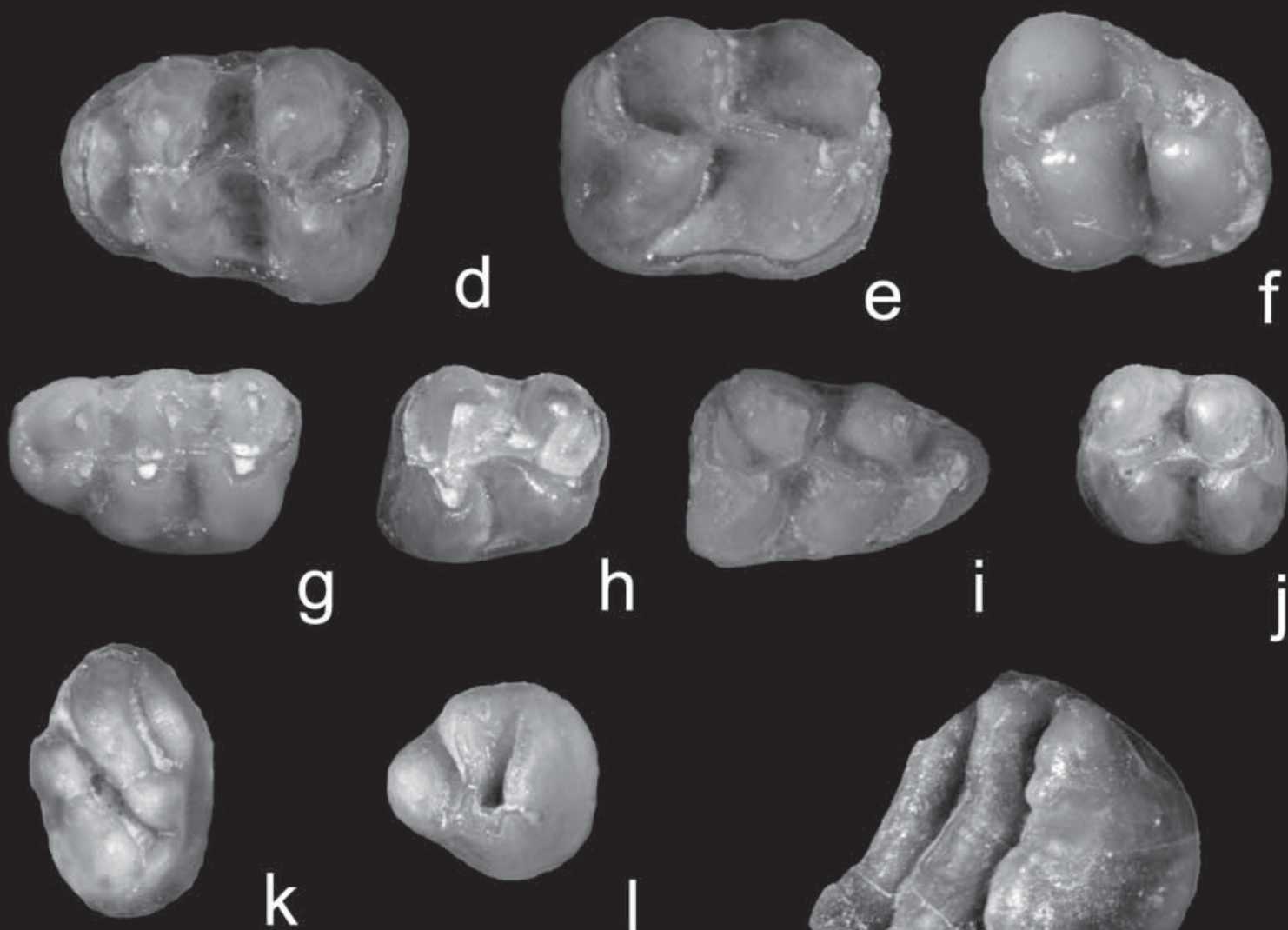

g
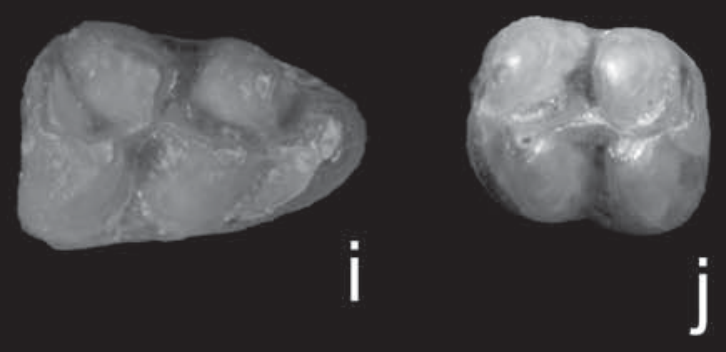

k
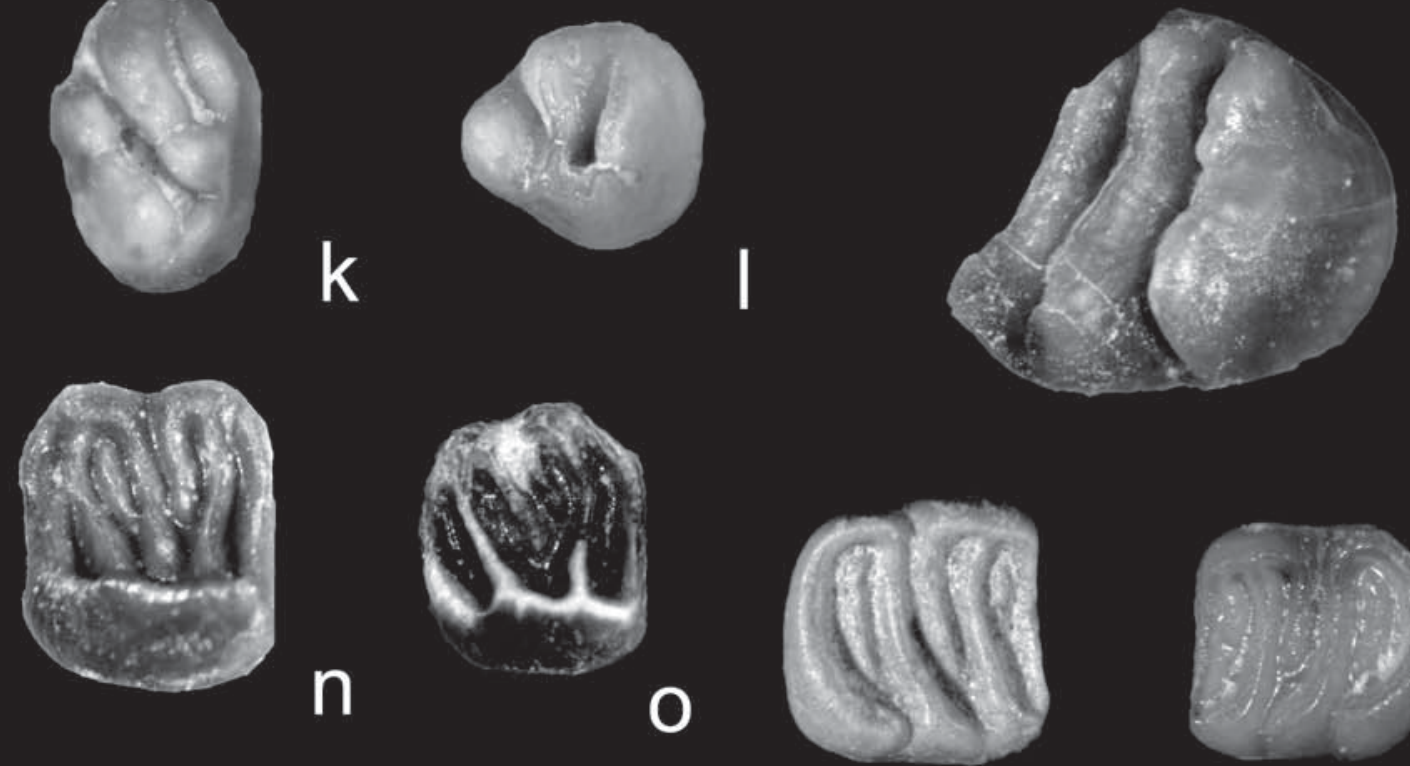

$\mathrm{m}$

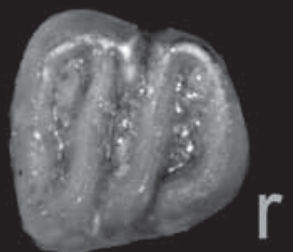

$\mathrm{p}$

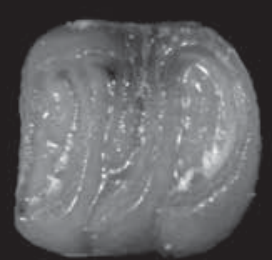

q 
Table 1. Measurements of Megacricetodon collongensis-gersii. (Measurements are given in mm, $\mathrm{N}=$ number of specimens; Av. = average; s.d. = standard deviation).

\begin{tabular}{|c|c|c|c|c|c|c|c|c|c|}
\hline \multirow[b]{2}{*}{ M. collong-gersii } & \multicolumn{4}{|c|}{ Length } & \multirow[b]{2}{*}{$\mathrm{N}$} & \multicolumn{4}{|c|}{ Width } \\
\hline & Min. & Av. & Max. & s.d. & & Min. & Av. & Max. & s.d. \\
\hline M1 & 1.58 & 1.64 & 1.69 & 0.045 & 5 & 1.00 & 1.07 & 1.12 & 0.049 \\
\hline M2 & 1.05 & 1.19 & 1.27 & 0.091 & 9 & 0.90 & 0.99 & 1.05 & 0.062 \\
\hline M3 & 0.68 & 0.79 & 0.85 & 0.070 & 13 & 0.70 & 0.78 & 0.88 & 0.074 \\
\hline $\mathrm{m} 1$ & 1.41 & 1.47 & 1.55 & 0.057 & 5 & 0.86 & 0.93 & 1.00 & 0.057 \\
\hline $\mathrm{m} 2$ & 1.12 & 1.17 & 1.22 & 0.040 & 10 & 0.97 & 1.00 & 1.05 & 0.033 \\
\hline $\mathrm{m} 3$ & 0.80 & 0.95 & 1.05 & 0.103 & 12 & 0.75 & 0.79 & 0.87 & 0.050 \\
\hline
\end{tabular}

m1: The anteroconid is simple in 4 out of 6 specimens, and it is slightly split in other two. The mesolophid is of medium length in 1 , short in 2 and absent in other two specimens.

m2: The lingual anterolophid is absent in 2 specimens, short in 5 and well developed in 1 specimens. The mesolophid is short length in 3 , and absent in other 5 specimens.

m3: The labial anterolophid is well developed, reaching the base of the protoconid, and it is short in the remaining ones. The lingual anterolophid is short in 6 out of 7 specimens and of a medium length in the other one. The metalophulid is directed forward in most cases, always before connecting the protoconid. The entoconid is reduced. The hipolophulid is always directed forward the protoconid, connecting to the back. The ectolophulid, present in all but one specimen, is directed forward and connecting with hipolophulid. The posterosenid and posterolophulid are always well developed. The senid is transverse in 3 out of 7 specimens and slightly directed backwards in the remaining ones.

Discussion. Menéndez Gamella et al. (2010) classified the material from Húmera as Megacricetodon collongensis. In this research, 38 new dental remains have been found in the last two field campaigns, allowing thus for a larger sample of this genus.

The most relevant morphological pattern of the new material are: anteroconid in $\mathrm{m} 1$ predominantly single or slightly divided, and the mesolophid short or absent; the $\mathrm{m} 2$ is characterized by a short lingual anterolophid, and mesolophid short or absent; well subdivided anteroloph in M1, and short mesoloph; and M2 with present ectoloph and variable length of the mesoloph. These features and the measurements are consistent with the data described by Menéndez Gamella et al. (2010), therefore the material from both campaigns can be considered together.

We have compared the Megacricetodon from Húmera with the material studied by Daams \& Freudenthal (1988) for the Megacricetodon primitivus-collongensis-crusafontiibericus lineage from the Aragonian type area (CalatayudDaroca Basin), and the material from the Madrid Basin studied by Herráez (1993) and Luis \& Hernando (2000).

The measurements from Húmera are very similar to Las Planas 4A, 4B, 4C, and slightly lower than Somosaguas, except M2, where the sizes are clearly larger, approaching Valalto $2 \mathrm{~b}$ and $2 \mathrm{C}$. The general morphological pattern of the genus Megacricetodon from Húmera is very similar to the material of Las Planas 4A, 4B and 4C (Daams \& Freudenthal, 1988), and to the material from Somosaguas described by Luis \& Hernando (2000). There are only some small differences in the lengths of mesoloph, which are slightly lower in M1 and smaller in the case of M2, with respect to fossil sites from the Calatayud-Daroca basin. However, the same features are shared with Somosaguas. The differences between different basins deposits could be due to ecological conditions, since the development of this character could be related to humidity (Daams et al., 1999b).

Menéndez Gamella et al. (2010) clasified this material as $M$. collongensis. However, Hernández-Ballarín et al.

Figure 3. a-f) Democricetodon larteti; a) M1 right, (HUM-213); b) M2 right, (HUM-218); c) M3 right, (HUM-226); d) m1 left, (HUM-245); e) M2 right, (HUM-256); f) $\mathrm{m} 3$ left, (HUM-276). g-j) Megacricetodon collongensis-gersii; g) M1 left, (HUM112); h) M2 left, (HUM-122); i) m1 right, (HUM-152); j) M2 left, (HUM-158). k-m) Armantomys tricristatus; k) P4 left, (HUM-425); 1) p4 left, (HUM-442); m) m3 left, (HUM-473). n), p-q) Microdyromys koenigswaldi; n) M1 left, (HUM494); p) m2 right, (HUM-499); q) m2 left, (HUM-498). o), r) Microdyromys aff. monspeliensis; o) M1 left, (HUM-495); r) m3 left, (HUM-497). 
(2011) have recently proposed to classify the populations of larger specimens within this species as M. collongensisgersii, which would be characteristic of the younger localities included in the Biozone E from the Madrid Basin. Our specimens are similar in size to those retrieved from the most recent fossil sites of the Madrid Basin, assigned to the Biozone E (Luís \& Hernando, 2000; HernándezBallarín et al., 2011), which allows us, therefore, to classify them as M. collongensis-gersii.

Genus Democricetodon Fahlbusch, 1964

Democricetodon larteti (Schaub, 1925)

(Figs 3a-3f)

Material. 4 M1, 8 M2, 14 M3, $7 \mathrm{~m} 1,6 \mathrm{~m} 2$ and $18 \mathrm{~m} 3$.

Measurements. Table 2.

M1: The anterocone is simple in all specimens and elongated in labial-lingual direction. The anterolophule is connected lingually to the anterocone; it is simple in 3 out of 4 specimens, and it is double in the remaining one. The protolophule is generally single, with the anterior branch, in three specimens, and it is double in other one. The ectoloph is lacking in 2 out of 4 specimens, whereas it is a short protuberance in the remaining two. None of the specimens present mesoloph. The metalophule is always posterior, reducing the posterosinus and posteroloph.

M2: The protolophule is always simple, transverse, and connected in front of the protocone in 5 out of 7 specimens, and posterior in other two. The ectoloph is a short protuberance in 5 out of 7 specimens, and it lacks in the remaining two. The mesoloph is absent in all specimens. The metalophule is posterior in 3 out of 7 specimens, anterior in one, and double in other two.

M3: The lingual anterolophule is well developed in all specimens, whereas the labial anterolophule is well developed in 10 out of 14 , poorly developed in three, and absent in other one. In the latter four specimens the protocone is poorly developed, whereas this and the paracone are the main cusps in the other specimens. The region behind the protocone and paracone is highly variable. The protolophule often appears to be connected forward to the protocone (in 7 out of 14), and it is absent or isolated in the remaining. Most specimens have the axioloph connected to the paracone and a centroloph with variable development.

m1: The antoroconid is simple. The mesolophid is of medium length in 1 , short in 4 , and absent in one specimen.

m2: The lingual anterolophid is short. The mesolophid is short in 1 out of 6 specimens, and absent in the remaining ones.

m3: The lingual anterosinusid is always well developed, whereas the labial anterosinusid is very poorly developed in 10 out of 18 specimens, and absent in the remaining ones. The metalophulid is always anterior, and the entoconid and mesolophid are absent.

Discussion. The material described by Menéndez Gamella et al. (2010) was so scarce that did not allow a specific diagnosis. In this paper, we have described 57 new molars, allowing us to make a precise arrangement.

The middle size species of the family Cricetidae in the Calatayud-Daroca Basin were reviewed by Van der Meulen et al. (2003), who considered the genera Fahlbuschia, Renzymis and Pseudofahlbhuschia synonyms of the genus Democricetodon. Although this interpretation was refused by Freudenthal (2006), we accept the synonymy proposed by Van der Meulen et al. (2003).

The presence of a simple anterocone in M1, in combination with the size of the specimens (Fig. 2), led us to consider the material from Húmera as belonging to the Democricetodon franconicus-crusafonti lineage. The split anterocone is predominant only in the younger forms of this lineage. The materials retrieved at Húmera shows clearly larger measurements than those of $D$. koenigswaldi, and are significantly smaller than those of the species $D$. crusafonti. Therefore, according to the combination of

Table 2. Measurements of Democricetodon larteti. (Measurements and abbreviations as in Table 1).

\begin{tabular}{|c|c|c|c|c|c|c|c|c|c|}
\hline \multirow[b]{2}{*}{ D. larteti } & \multicolumn{4}{|c|}{ Length } & \multirow[b]{2}{*}{$\mathrm{N}$} & \multicolumn{4}{|c|}{ Width } \\
\hline & Min. & Av. & Max. & s.d. & & Min. & Av. & Max. & s.d. \\
\hline M1 & 2.45 & 2.47 & 2.50 & 0.021 & 3 & 1.55 & 1.62 & 1.75 & 0.083 \\
\hline M2 & 1.75 & 1.86 & 1.90 & 0.063 & 4 & 1.55 & 1.57 & 1.60 & 0.021 \\
\hline M3 & 1.15 & 1.28 & 1.45 & 0.123 & 16 & 1.10 & 1.37 & 1.50 & 0.167 \\
\hline $\mathrm{m} 1$ & 1.95 & 2.01 & 2.05 & 0.041 & 6 & 1.28 & 1.37 & 1.42 & 0.058 \\
\hline $\mathrm{m} 2$ & 1.81 & 1.89 & 1.95 & 0.057 & 6 & 1.45 & 1.52 & 1.60 & 0.061 \\
\hline $\mathrm{m} 3$ & 1.35 & 1.55 & 1.70 & 0.144 & 19 & 1.15 & 1.34 & 1.55 & 0.163 \\
\hline
\end{tabular}


the dental pattern and the size, we can assign the studied material to the species Democricetodon larteti.

Family Gliridae Muirhead, 1819

Genus Armantomys De Bruijn, 1966

Armantomys tricristatus López-Martínez, 1977

(Figs 3k-3m)

Material. 15 P4, 2 M1-M2, 1 M3, 30 p4, 2 m1-m2 and $1 \mathrm{~m} 3$.

Measurements. Table 3.

P4: The outline of the teeth is generally oval, or subtriangular in some specimens. The anteroloph is absent, and protoloph and metaloph are oblique ridges. The protoloph is the more developed ridge, and it is divided in 12 out of 15 specimens. The metaloph is always present. It is an isolated ridge in 8 out of 15 specimens, and it joins the posteroloph in 7 . The posteroloph is short, but longer than the metaloph in 3 specimens.

M1-M2: Some fragments of molars can be attributed to these pieces, but due to their state of preservation, a precise description is not feasible.

M3: The anteroloph is broken at the lingual area. The protoloph is a narrow isolated ridge. The metaloph and posteroloph join in the labial part as well as in the medium-lingual one.

p4: These elements have a rounded subtriangular outline. The dental pattern is simple, consisting of three cusps-like ridges. These ridges are isolated in 5 out of 30 specimens. The anterior elongated cusp joins the labial part of the mesolophid in 13 out of 30 specimens, and the labial part of the posterolophid in 5 out of 30 specimens. In 7 specimens the anterior cusp is connected to both the mesolophid and posterolophid.

m1-m2: Some fragments of molars can be attributed to these pieces, but like the upper molars, their state of preservation does not allow a precise description of them.

m3: The only specimen is broken and it does not preserve the anterolophid. The mesolophid and posterolophid are complete and isolated.
Discussion. Only three premolars were described by Menéndez Gamella et al. (2010). Therefore, the 51 teeth described on this paper have allowed us to provide an accurate diagnosis.

Based on the measurements and the morphology, we can assign the material from Húmera to Armantomys aragonensis-tricristatus lineage. Daams (1991) characterized in this lineage the following trends towards: (1) size increase of the molars, (2) more inclination of the ridges, (3) loss of the anterocone in P4, (4) connection between metaloph and posteroloph in the upper molars, (5) shortening of the anterolophid in the lower molars, and (6) a more complete ridge pattern of $\mathrm{m} 3$. Besides, the ridges of the M3 of $A$. triscristatus are more or less semicircular in occlusal view, while in $A$. aragonensis the ridges are more transverse.

Although the diagnostic material is broken in the specimens from Húmera, we can observe that P4 lacks anterocone, the $\mathrm{m} 3$ has the mesolophid and posterolophid completely isolated, and the M3 has the metaloph and posteroloph connected, with the other ridges being semicircular. The inclination of the ridges is strong in the upper and lower molars. Therefore, although some material is very fragmentary, we think that all these characteristics allow us to classify our specimens as Armantomys tricristatus.

Genus Microdyromys De Bruijn, 1966

$$
\text { Microdyromys koenigswaldi De Bruijn, } 1966
$$

(Figs 3n, 3p-3q)

\section{Material and measurements. Table 4.}

P4: There is only one specimen. Its outline is oval. The anteroloph is of medium length and isolated. The protoloph and the metaloph are large and connected to the endoloph. This specimen has a posterior centroloph, which does not connect completely to the metaloph. The posteroloph is short and isolated. This specimen shows morphotype E by Daams (1981).

M1: The only specimen has a concave occlusal surface and a subrectangular outline. Anteroloph, protoloph, metaloph and posteroloph are well developed. The anterior centroloph is more developed than the posterior one. There

Table 3. Measurements of Armantomys tricristatus. (Measurements and abbreviations as in Table 1).

\begin{tabular}{|c|c|c|c|c|c|c|c|c|c|}
\hline \multirow[b]{2}{*}{ A. tricristatus } & \multicolumn{4}{|c|}{ Length } & \multirow[b]{2}{*}{$\mathrm{N}$} & \multicolumn{4}{|c|}{ Width } \\
\hline & Min. & Av. & Max. & s.d. & & Min. & Av. & Max. & s.d. \\
\hline P4 & 0.98 & 1.13 & 1.30 & 0.130 & 17 & 1.48 & 1.71 & 1.88 & 0.164 \\
\hline $\mathrm{p} 4$ & 0.85 & 1.05 & 1.32 & 0.192 & 31 & 0.83 & 1.00 & 1.15 & 0.131 \\
\hline
\end{tabular}


is an extra ridge between the protoloph and the anterior centroloph. This specimen shows morphotype H by Daams (1981).

m2: The anterolophid and the metalophid are well developed, and the anterolophid connects to the protoconid. The metalophid connects with the metaconid in two specimens. The centrolophid is well developed, but it does not reach the lingual border. The larger specimen shows a poorly-developed posterior extra ridge. Posterolophid and mesolophid connect to the entoconid, reaching the lingual border. The two specimens have a well-developed anterior extra ridge. These specimens show morphotypes 2 and 3 by Daams (1981).

\section{Microdyromys aff. monspeliensis Aguilar, 1977} (Figs 3o, 3r)

\section{Material and measurements. Table 4.}

M1: The only specimen has a concave occlusal surface and it is a subrectangular outline. The measurements of this specimen should be regarded as approximate, since the tooth has lost some enamel cover (possible acid digestion process), and therefore, the size obtained is slightly lower than real size. Anteroloph, protoloph, metaloph and posteroloph are well developed. The anterior centroloph is more developed than the posterior one. This specimen does not present an extra ridge, showing morphotype $G$ by Daams (1981).

m3: The anterolophid does not reach the protoconid, but it joins metalophid through metaconid. The centrolophid is very short and connects to the metaconid. Posterolophid and mesolophid are connected to the entoconid, not reaching the lingual border. The tooth has a poorly-developed anterior extra ridge, but it does not have any posterior extra ridge, which means that it does not correspond to any morphotypes by Daams (1981).

Discussion. Five Microdyromys species are recognized in the Spanish Miocene: M. legidensis, M. monspeliensis,
M. koenigswaldi, M. complicatus and M. remmerti (Daams, 1981; García-Paredes et al., 2010). The first three species were mentioned in the Madrid basin (Herráez, 1993; Peláez-Campomanes et al., 2003; Hernández-Ballarín et al., 2011). Microdyromys legidensis and M. koenigswaldi appear together in most of the Middle Aragonian (biozones Dc and Dd), while M. koenigswaldi and M. monspeliensis do so in the latter Middle Aragonian and the Upper Aragonian.

Despite the scarce material from Húmera, we can clearly distinguish two size groups, which are associated with different morphological patterns. The largest specimens have a more complex dental pattern, showing morphotype H by Daams (1981) in upper molars, while the smallest specimens show simpler patterns (morphotype G by Daams, 1981).

The morphological patterns and measurements of the largest specimens are characteristic of $M$. koenigswaldi. Although the measurements are slightly larger than those of the type population of this species, described by De Bruijn (1966), we classify the Húmera material as Microdyromys koenigswaldi, given their morphological similarities.

The size of the smallest pieces is similar to those of M. monspeliensis, although some of their morphological characters do not match completely. Material as this one has been assigned to M. monspeliensis and $M$. aff. monspeliensis (sensu Daams, 1981) in other sites from the Madrid basin (Herráez, 1993; García-Paredes et al., 2010; Hernández-Ballarín et al., 2010, 2011). Given the small differences in morphological characters, we prefer to classify it as Microdyromys aff. monspeliensis.

Family Sciuridae Fischer von Waldheim, 1817 Genus Heteroxerus Stehlin \& Schaub, 1951

$$
\begin{gathered}
\text { Heteroxerus rubricati Crusafont, Villalta \& } \\
\text { Truyols, 1955 } \\
\text { (Figs 4a-4c) }
\end{gathered}
$$

Material. 3 P4, 1 M1-M2, $7 \mathrm{M} 3,4 \mathrm{p} 4$ and $4 \mathrm{~m} 3$.

\begin{tabular}{|c|c|c|c|c|c|c|c|}
\hline \multirow[b]{2}{*}{ M. koenigswaldi } & \multicolumn{2}{|c|}{ Length } & \multirow[b]{2}{*}{ Max. } & \multirow[b]{2}{*}{$\mathrm{N}$} & \multicolumn{2}{|c|}{ Width } & \multirow[b]{2}{*}{ Max. } \\
\hline & Min. & Av. & & & Min. & Av. & \\
\hline $\mathrm{P} 4$ & & 0.85 & & 1 & & 1.15 & \\
\hline M1 & & 1.13 & & 1 & & 1.38 & \\
\hline $\mathrm{m} 2$ & 1.17 & 1.21 & 1.25 & 2 & 1.11 & 1.19 & 1.27 \\
\hline \multicolumn{8}{|c|}{ M. aff. monspeliensis } \\
\hline M1 & & 1.02 & & 1 & & 1.15 & \\
\hline $\mathrm{m} 3$ & & 1.03 & & 1 & & 1.05 & \\
\hline
\end{tabular}

Table 4. Measurements of Microdyromys koenigswaldi and Microdyromys aff. monspeliensis. (Measurements and abbreviations as in Table 1). 
Table 5. Measurements of Heteroxerus rubricati. (Measurements and abbreviations as in Table 1).

\begin{tabular}{|c|c|c|c|c|c|c|c|c|c|}
\hline \multirow[b]{2}{*}{ H. rubricati } & \multicolumn{4}{|c|}{ Length } & \multirow[b]{2}{*}{$\mathrm{N}$} & \multicolumn{4}{|c|}{ Width } \\
\hline & Min. & Av. & Max. & s.d. & & Min. & Av. & Max. & s.d. \\
\hline $\mathrm{P} 4$ & 1.22 & 1.30 & 1.38 & 0.065 & 3 & 1.55 & 1.59 & 1.62 & 0.029 \\
\hline M1-M2 & & 1.50 & & & 1 & & 1.90 & & \\
\hline M3 & 1.45 & 1.55 & 1.60 & 0.062 & 8 & 1.55 & 1.67 & 1.81 & 0.106 \\
\hline $\mathrm{p} 4$ & 1.38 & 1.45 & 1.48 & 0.041 & 4 & 1.25 & 1.30 & 1.35 & 0.040 \\
\hline $\mathrm{m} 3$ & 1.70 & 1.80 & 1.85 & 0.062 & 5 & 1.67 & 1.72 & 1.80 & 0.054 \\
\hline
\end{tabular}

Measurements. Table 5.

P4: The specimens have a subrectangular outline with rounded border. The anteroloph is low, short and thin in two specimens, whereas this character cannot be observed in the other one. The anteroconule is absent. The protocone is the highest cusp in the three specimens, and the hypocone is small and located lingually with respect to the protocone. The protoloph is short and the protoconule is absent. One specimen has a small hypoconule. The paracone is always well developed. The mesostyle is absent. The metacone and metaconule are developed, and they are connected by a small metaloph. The low posteroloph is poorly developed, and it does not join the metaloph.

M1-M2: Tooth of subcuadrangular outline. The labial border is longer than the lingual one. The four main cusps are well developed: protocone, paracone, metacone and hipocone. The protocone is the largest cusp. The anteroloph is large and the anteroconule is poorly developed. The protoloph is large without protoconule. The metaloph is short. The metaconule is well developed and it does not join the posteroloph (morphotype 2 by CuencaBescós, 1988). The posteroloph is a low ridge, and it has a well developed hypoconule. The mesostyle is absent. The parastyle is a small cusp on the labial border of the anteroloph.

M3: The outline of these elements is generally subrounded. There are two main cusps, the protocone and paracone, connected by the protoloph. Generally, the protoloph is wide in its middle part, in relation to a smaller protoconule. The protoconule is absent in 2 specimens. The anteroloph is well developed, being the anteroconule poorly developed in 4 out of 8 specimens, and absent in the remaining ones. The hypocone is usually poorly developed. The metaconule is isolated in 6 out of 8 specimens and conneted to the posteroloph in two specimens.

p4: Teeth of trapezoidal outline. The four main cusps, protoconid, metaconid, entoconid and hipoconid, are well developed. The anteroconid is small, and the protoconid and metaconid are very close each other, resulting in the anterior part being narrower than the posterior one. The posterolophid is reduced, and it is a narrow ridge. The entolophid is directed backward, connecting with a small hypoconulid in 3 out of 4 specimens. In one specimen, the entolophid is wider in its labial part, isolating the hypoconulid.

m3: The outline is triangular, with the anterior part slightly wider than the posterior one. The three main cusps are metaconid, protoconid and hypoconid, and the entoconid is reduced. The anterior cingulum is absent in 1 out of 4 specimens, poorly developed in 2 out of 4 , and well developed in one specimens (morphotypes 5, 6 and 7 respectively by Cuenca-Bescós, 1988). A tiny anteroconulid is present. The ectolophid is complete, and the metalophid ends free in the central basin. The mesolophid and metaconid are absent. The entolophid is complete in 2 out of 5 specimens, and incomplete in three. The posterolophid is a thick short ridge.

\section{Heteroxerus grivensis (Forsyth Major, 1893) (Figs 4d-4e)}

\section{Material and measurements. Table 6.}

M1-M2: The outline is subcuadrangular. The labial border is longer than the lingual one. The four main cusps are well developed. The paracone is the highest cusp. The anteroloph is large and the anteroconule is poorly developed. The protoloph is large without protoconule. The metaloph is short. The metaconule is well developed, and it joins the posteroloph (morphotype 3 by CuencaBescós, 1988). The low posteroloph has a well-developed hypoconule in one specimen, but it is poorly-developed in other one. The mesostyle is absent. The parastyle is a small cusp on the labial border of the anteroloph.

m2: This specimen has a slightly rhomboidal outline. Of the four main cusps, the metaconid is the best developed. A small anteroconulid is present. The anterior cingulum is well developed, and it is only connected to the protoconid (morphotype 7 by Cuenca-Bescós, 1988). The anterolophid is a residual ridge. The incomplete metalophid ends free in the central basin. The ectolophid is complete. The mesolophid and mesoconid are absent. The entolophid is complete and it joins the hypoconulid. The posterolophid is reduced. 

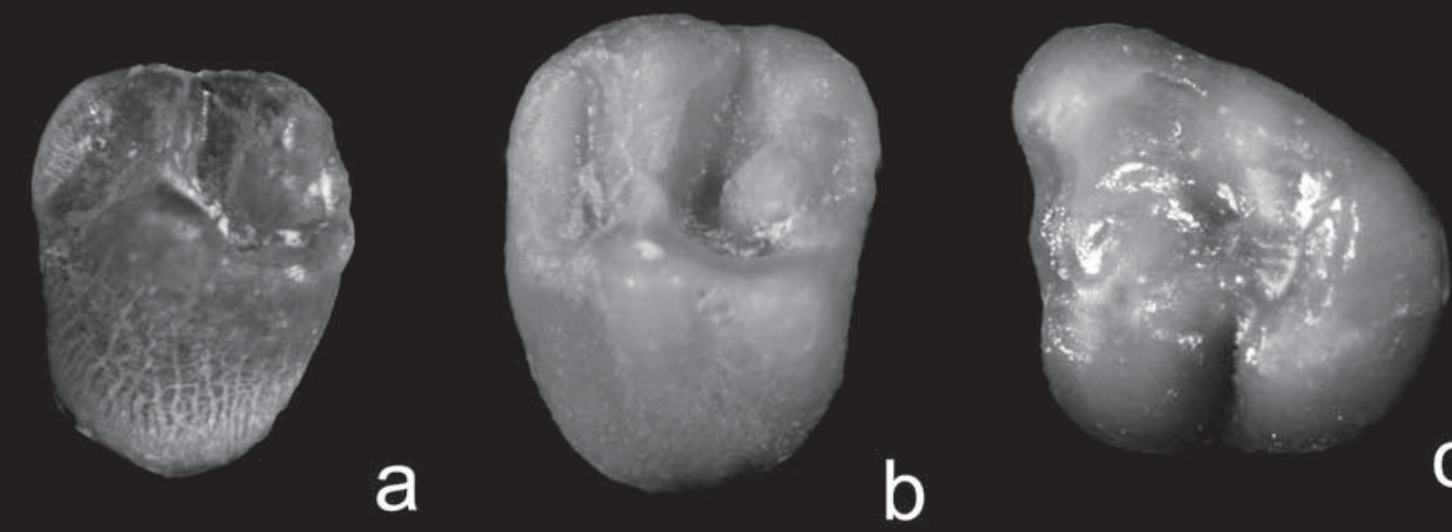

b

C
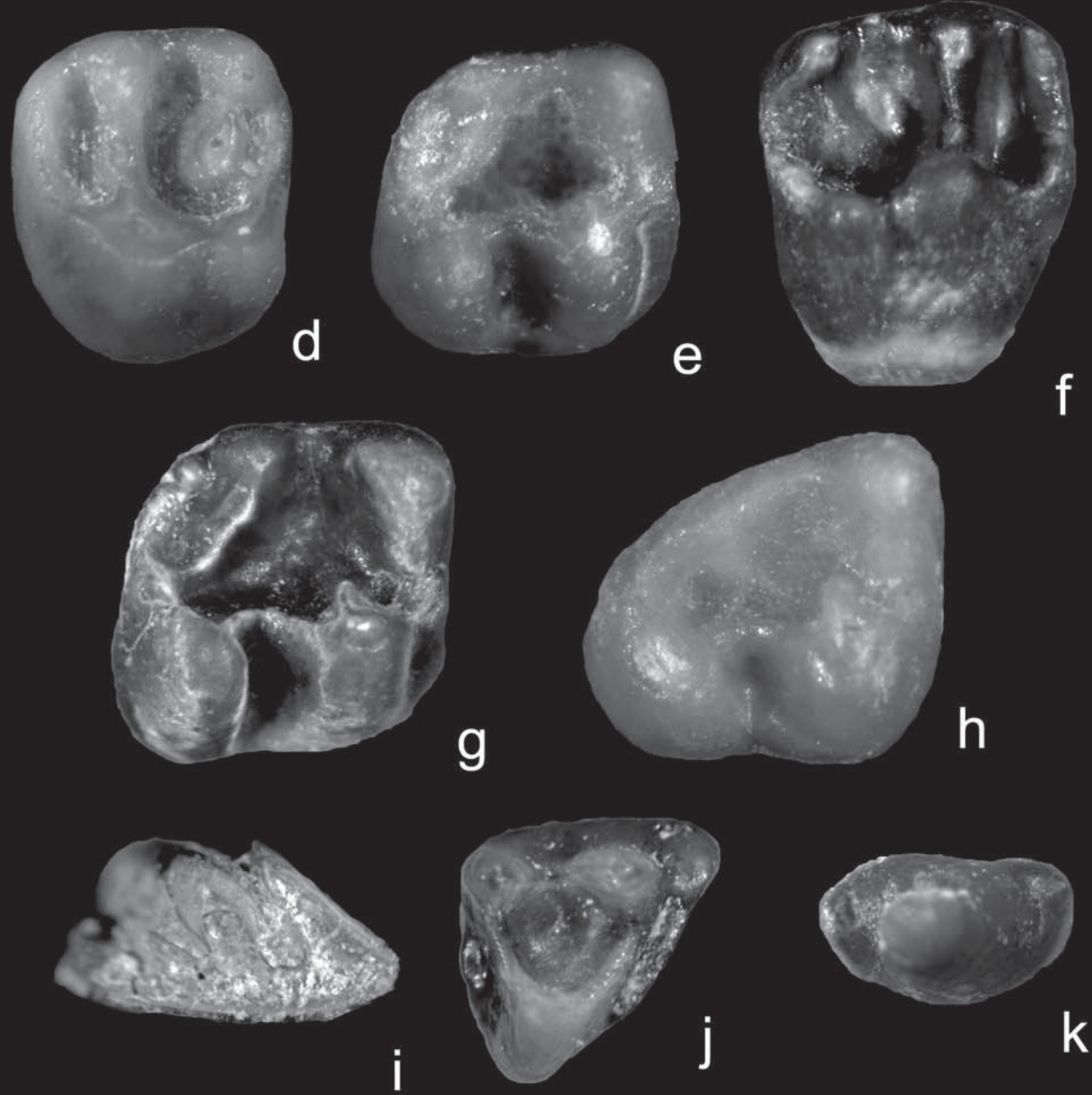
Table 6. Measurements of Heteroxerus grivensis. (Measurements and abbreviations as in Table 1).

\begin{tabular}{|c|c|c|c|c|c|c|c|}
\hline \multirow[b]{2}{*}{ H. grivensis } & \multicolumn{4}{|c|}{ Length } & \multicolumn{3}{|c|}{ Width } \\
\hline & Min. & Av. & Max. & $\mathrm{N}$ & Min. & Av. & Max. \\
\hline M1-M2 & & 1.68 & & 1 & & 1.98 & \\
\hline $\mathrm{m} 2$ & & 1.75 & & 1 & & 1.80 & \\
\hline $\mathrm{m} 3$ & & 1.88 & & 1 & & 1.85 & \\
\hline
\end{tabular}

m3: The outline is triangular, with the anterior part slightly wider than the posterior one. The three main cusps are metaconid, protoconid and hypoconid, and the entoconid is reduced. The anterior cingulum is absent (morphotype 5 by Cuenca-Bescós, 1988). A tiny anteroconulid is present. The ectolophid is complete, and the metalophid ends free in the central basin. The mesolophid, metaconid and entolophid are absent. The posterolophid is a thick short ridge.

\section{Heteroxerus sp.}

(Figs 4f-4h)

\section{Material and measurements. Table 7.}

M1-M2: This specimen has a subcuadrangular outline. The labial border is longer than the lingual one. The four main cusps are well developed. The protocone is the highest of the four main cusps. The anteroloph is large and the anteroconule is poorly developed. The protoloph is large without protoconule. The short metaloph shows a metaconule well developed and it is not connected to the posteroloph (morphotype 2 by Cuenca-Bescós, 1988). The posteroloph is low, with a well developed hypoconule in one specimen, and poorly-developed in other one. The mesostyle is absent. The parastyle is present.

m2: Tooth with slightly rhomboidal outline. The metacone is the top of the four main cusps. A small anteroconulid is present. The anterior cingulum is present and connected to the protoconid (morphotype 7 by CuencaBescós, 1988). The anterolophid is a residual ridge. The incomplete metalophid ends free in the central basin. The ectolophid is complete. The mesolophid and mesoconid are absent. The entolophid is complete and connected to the hypoconulid. The posterolophid is reduced.

m3: The tooth outline is triangular. The anterior border is wider than the posterior one. The entoconid is reduced. The anterior cingulum is absent (morphotype 5
Table 7. Measurements of Heteroxerus sp. (Measurements and abbreviations as in Table 1).

\begin{tabular}{|c|c|c|c|c|c|c|c|}
\hline \multirow[b]{2}{*}{ H. sp. } & \multicolumn{4}{|c|}{ Length } & \multicolumn{3}{|c|}{ Width } \\
\hline & Min. & Av. & Max. & $\mathrm{N}$ & Min. & Av. & Max. \\
\hline M1-M2 & & 1.85 & & 1 & & 2.32 & \\
\hline $\mathrm{m} 2$ & & 2.04 & & 1 & & 2.08 & \\
\hline $\mathrm{m} 3$ & & 2.07 & & 1 & & 1.90 & \\
\hline
\end{tabular}

by Cuenca-Bescós, 1988). The ectolophid is complete. The posterolophid is a thick short ridge. The mesolophid, metaconid and entolophid are absent. The metalophid ends free in the central basin.

Discussion. Menéndez Gamella et al. (2010) only had two third molars, being thus impossible to identify a specific level. Now the material is being completed with a further 20 new pieces, allowing for better observations.

The Heteroxerus material from Húmera has been assigned to three different species. Most of the material belongs to $H$. rubricati (the smallest species), whereas a small number of specimens have been identified as $H$. grivensis and Heteroxerus sp. This material shows very similar morphological patterns, differing only by the size, which agrees with the material of the different species of Heteroxerus from the Calatayud-Montalbán basin described by Cuenca-Bescós (1988).

We found three molars, which show a larger size than those of Heteroxerus grivensis. Such large size populations of terrestrial squirrels have been found previously in the Middle Miocene at the Calatayud-Montalbán and the Madrid basins and they have been described as Heteroxerus sp. (Cuenca-Bescós, 1988; López-Guerrero et al., 2007).

Order LAGOMORPHA Brandt, 1855

Family Ochotonidae Thomas, 1897

Genus Lagopsis Schlsser, 1884

Lagopsis sp.

(Fig. 4i)

\section{Material. 1 P2.}

P2: The postlobule is broken. The paraflexus and mesoflexus are oblique and parallel, and the hipoflexus is absent. The hipercone is triangular and projected forward at the same height as the lagicone.

Figure 4. a-c) Heteroxerus rubricati; a) P4 left, (HUM-312); b) M1-M2 left, (HUM-314); c) m3 left, (HUM-345). d-e) Heteroxerus grivensis; d) M1-M2 left, (HUM-315); e) m2 right, (HUM-339). f-h) Heteroxerus sp. f) M1-M2 right, (HUM-316); g) m2 right, (HUM-341); h) m3 right, (HUM-346). i) Lagopsis sp. P2 right, (HUM-525). j-k) Galerix sp. j) M3 right, (HUM512); k) p3 right, (HUM-513). 
Discussion. The scarce material from Húmera does not allow identification at the species level. Only oblique flexus allow us to state that our specimen belongs to the Lagopsis genus (López-Martínez, 1989).

Order INSECTIVORA Cuvier, 1817

Family Erinaceidae Bonaparte, 1838

Genus Galerix Pomel, 1808

\section{Galerix sp. \\ (Figs $4 \mathrm{j}-4 \mathrm{k}$ )}

Material and measurements. $1 \mathrm{M} 3$ (L: 1.50; W: 1.85), 1 p3 (L: 1.40; W: 0.85).

M3: The outline of the occlusal surface is triangular. The paracone is the highest cusp, above the metacone and protocone. The two arms of the protocone are connected to the paracone and metacone, respectively. The parastylid is very well developed. This ridge lays anterolabially of the paracone and it is connected to its base. The anterior side of the paracone is rounded. There is a well-developed anterior cingulum. The labial cingulum is very poorly developed, being limited to the anterior part. The posterior cingulum is poorly developed.

p3: The tooth outline is subelliptical, with a straight posterior side. This premolar is lingually longer than labially. The tip of the main cusp is situated in the centre of the tooth, and it shows anterior and posterior tiny accessory cusps.

p4: Two broken and isolated premolars have been found. The most remarkable features of these premolars are the high and sharp protoconids, and lack well-defined metaconids. The talonid is broken in both specimens. In lateral view, the metaconid is situated halfway the protoconid, and both cusps are joined by a low posterior ridge. In the only specimen where is possible to see, the paraconid is a well-individualized cusp.

Discussion. The taxonomic classification of Galerix is difficult because of its high morphological variation. Characters are rarely unequivocal, and there always seem to be exceptions to the rule (Van den Hoek Ostende, 2001). Morphological characters used to distinguish between species are the presence or absence of a hypocone on the P3, the development of the metaconid and the paralophid on the $\mathrm{p} 4$, and the development of the ridges between protocone, hypocone and metaconule (Van den Hoek Ostende, 2003).

Only 4 specimens have been recovered: M3, p3 and two broken $\mathrm{p} 4$, being therefore impossible to observe the aforementioned diagnostic characters, except for the metaconids of the $\mathrm{p} 4$, whose lack of proper definition a typical featurel of Galerix (Furió et al., 2011). The measurements are also characteristic of this genus.
In addition to the described micromammals, two indeterminate reptilian teeth have been also found, as well as some taxa of macromammals such as Gomphotherium angustidens, Heteroprox moralesi and Anchitherium sp. (Menéndez Gamella et al., 2010; Morales, pers. comm. 2012).

\section{BIOSTRATIGRAPHY}

The micromammals biostratigraphy from the Madrid Basin was reviewed by Peláez-Campomanes et al. (2003) and Hernández-Ballarín et al. (2011), recognizing the subdivisions proposed by Daams et al. (1999a) for the Aragonian from the Calatayud-Montalbán Basin, mainly based on the stratigraphic distribution of various Cricetidae species of the genera Megacricetodon, Democricetodon and Cricetodon.

The fossil association from Húmera allows a precise correlation with the proposed biostratigraphic scale. The presence of Democricetodon larteti and Megacricetodon collongensis-gersii, only occurs on the biozone E (Daams et al., 1999a), both in the deposits from the CalatayudMontalbán and the Madrid basins. The presence of an advanced state of Megacricetodon collongensis, in transition with $M$. gersii, would indicate a younger age within the biozone E (Hernández Ballarín et al., 2011). Moreover, this correlation with the biozone $\mathrm{E}$, could be reinforced with the presence of three species of Heteroxerus (H. rubricati, $H$. grivensis and Heteroxerus. sp.), as in other fossil sites such as Las Planas 4 or Casa Montero from the CalatayudMontalbán and the Madrid basins, respectively (LópezGuerrero et al., 2007; Hernández Ballarín et al., 2011).

This biozone was poorly represented in the Madrid Basin, until the relatively recent discovery of Somosaguas, Casa Montero and El Cañaveral fossil sites (Luís \& Hernando, 2000; Hernández-Ballarín et al., 2011). Recent magnetostratigraphic dating, from the Calatayud-Daroca basin, locate the biozone E between 13.80 and $14.06 \mathrm{Ma}$ (Van Dam et al., 2006).

\section{CONCLUSIONS}

The new data extracted from the Húmera fossil site can be assigned to the biozone $\mathrm{E}$ from the Madrid basin. The faunal list of Húmera includes: Megacricetodon collongensis-gersii, Democricetodon larteti, Armantomys tricristatus, Microdyromys aff. monspeliensis, Microdyromys koenigswaldi, Heteroxerus rubricati, Heteroxerus grivensis, Heteroxerus sp., Lagopsis sp., Galerix sp., Gomphotherium angustidens, Heteroprox moralesi, Anchitherium sp. and Reptilia indet. 


\section{ACKNOWLEDGEMENTS}

This paper is dedicated to our dear teacher and friend Nieves López Martínez, who transmitted us her enthusiasm for palaeontology. The interest and support of Nieves were essential to the protection and knowledge of the Húmera fossil site. We want to thank all colleagues and students that helped us in the field works and in the preparation of this paper, specially to the Palaeontological team of Somosaguas, to Jorge Morales for his interest and help, to Pablo Peláez-Campomanes, Israel García Paredes, Manuel Hernández Fernández, and anonymous reviewer, for the critical reading of the document, to Emilia Nogueras for the fast processing of the excavation permissions, and to Serhiy Kryvosheya and Steven Ramírez for helping us collecting the samples during their practices in Geosfera, within $4^{\circ}$ ESO+Empresa project of the Comunidad de Madrid. Last, to the Dirección General de Patrimonio Histórico de la Comunidad de Madrid, that sponsored the intervention under the agreement signed with the National Museum of Natural Sciences, CSIC.

\section{REFERENCES}

Alberdi, M.T., Hoyos, M., Junco, F., López-Martínez, N., Morales, J., Sesé, C. \& Soria, D. 1984. Biostratigraphy and sedimentary evolution of continental Neogene in the Madrid basin. Paléobiologie Continentale, 14, 47-68.

Alonso-Zarza, A.M., Calvo, J.P., Silva, P.G. \& Torres, T. 2004. Cuenca del Tajo. In: Geología de España (ed. Vera, J.A.). Instituto Geológico y Minero de España, Madrid, 556-560.

Calvo, J.P., Daams, R., Morales, J., López-Martínez, N., Agustí, J., Anadón, P., Armenteros, I., Cabrera, L., Civis, J., Corrochano, A., Díaz-Molina, M., Elizaga, E., Hoyos, M., Martín-Suárez, E., Martínez, J., Moissenet, E., Muñoz, A., Pérez-García, A., Pérez-González, A., Portero, J.M., Robles, F., Santisteban, C., Torres, T., Van Der Meulen, A.J., Vera, J.A. \& Mein, P. 1993. Up-to-date Spanish continental Neogene synthesis and paleoclimatic interpretation. Revista de la Sociedad Geológica de España, 63 (4), 29-40.

Cuenca-Bescós, G. 1988. Revisión de los Sciuridae del Aragoniense y del Rambliense en la fosa de CalatayudMontalbán. Scripta Geologica, 87, 1-116.

Daams, R. 1981. The dental pattern of the Dormice Dryomys, Myomimus, Microdyromys and Peridyromys. Utrech Micropaleontological Bulletins, 3, 1-115.

Daams, R. 1991. Hypsodont Myomiminae (Gliridae, Rodentia) from the Miocene and the Oligocene-Miocene boundary interval of Spain. Scripta Geologica, 95, 1-63.

Daams, R. \& Freudenthal, M. 1988. Cricetidae (Rodentia) from the type-Aragonian; the genus Megacricetodon. In: Biostratigraphy and palaeoecology of the Neogene
Micromammalian faunas from the Calatayud-Teruel Basin (Spain) (ed. Freudenthal, M.). Scripta Geologica, Special Issue, 1, 39-132.

Daams, R. \& Van der Meulen, A.J. 1984. Paleoenvironmental and paleoclimatic interpretation of micromammal faunal successions in the Upper Oligocene and Miocene of northcentral Spain. Paléobiologie Continentale, 14, 241257.

Daams, R., Van der Meulen, A.J., Álvarez Sierra, M.A., Peláez-Campomanes, P., Calvo, J.P., Alonso Zarza, M.A. \& Krijgsman, W. 1999a. Stratigraphy and sedimentology of the Aragonian (Early to Middle Miocene) in its type area (North-Central Spain). Newsletters on Stratigraphy, 37 (3), 103-139.

Daams, R., Van der Meulen, A.J., Peláez-Campomanes, A.J. \& Álvarez Sierra, M.A. 1999b. Trends in rodents assemblages from the Aragonian (Early Middle Miocene) of the Calatayud-Daroca Basin (Aragón, Spain). In: Hominoid Evolution and Climate Change in Europe. 1 The Evolution of Neogene Terrestrial Ecosystems in Europe (eds. Agusti, J., Rook, L. \& Andrews, P.). Cambridge University Press, Cambridge, 127-139.

De Bruijn, H. 1966. Some new Miocene Gliridae from the Calatayud area (Prov. Zaragoza, Spain). Procedings of the Koninklijke Nederlandse Akademie Van Wetenschappen, B, 69, 3, 58-78.

De Vicente, G., Vegas, R., Muñoz Martín, A., Silva, P.G., Andriessen, P., Cloetingh, S., González Casado, J.M., Van Wees, J.D., Álvarez, J., Carbó, A. \& Olaiz, A. 2007. Cenozoic thick-skinned deformation and topography evolution of the Spanish Central System. Global and Planetary Change, 58, 335-381.

Domingo, L., Cuevas-González, J., Grimes, S.T., Hernández Fernández, M. \& López-Martínez, N. 2009. Multiproxy reconstruction of the palaeoclimate and palaeoenvironment of the Middle Miocene Somosaguas site (Madrid, Spain) using herbivore dental enamel. Palaeogeography, Palaeoclimatology, Palaeoecology, 272, 53-68.

Domingo, L., Koch, P.L., Grimes, S.T., Morales, J. \& LópezMartínez, N. 2012. Isotopic paleoecology of mammals and the Middle Miocene Cooling event in the Madrid Basin (Spain). Palaeogeography, Palaeoclimatology, Palaeoecology, 339-341, 98-113.

Freudenthal, M. 2006. The status of Democricetodon, Fahlbuschia, Pseudofahlbuschia and Renzimys (Cricetidae, Mammalia). A reply to van der Meulen et al. (2004). Geobios, 39, 43-55.

Freudenthal, M., Hugueney, M. \& Moisenet, E. 1994. The genus Pseudocricetodon (Cricetidae, Mammalia) in the Upper Oligocene of the province of Teruel (Spain). Scripta Geologica, 104, 57-114.

Furió, M., Casanovas-Vilar, I., Moyà-Solà, S., Köhler, M., Galindo, J. \& Alba, D.M. 2011. Insectivores (Eulipotyphla; Mammalia) from the Middle Miocene of Barranc de Can Vila 1 (Vallès-Penedès Basin, Catalonia, Spain). Geobios, 44, 199-213.

García-Paredes, I., Peláez-Campomanes, P. \& ÁlvarezSierra, M.A. 2010. Microdyromys remmerti, sp. nov., a 
new gliridae (rodentia, mammalia) from the Aragonian type area (Miocene, Calatayud-Montalban basin, Spain). Journal of Vertebrate Paleontology, 30 (5), 1594-1609.

Hernández Fernández, M., Cárdaba, J.A., Cuevas-González, J., Fesharaki, O., Salesa, M.J., Corrales, B., Domingo, L., Elez, J., López Guerrero, P., Sala-Burgos, N., Morales, J. \& López-Martínez, N. 2006. Los yacimientos de vertebrados del Mioceno medio de Somosaguas (Pozuelo de Alarcón, Madrid): implicaciones paleoambientales y paleoclimáticas. Estudios Geológicos, 62, 263-294.

Hernández-Ballarín, V., Oliver, A., García-Paredes, I. \& Peláez-Campomanes, P. 2010. Estudio preliminar de la fauna de roedores del yacimiento mioceno de El Cañaveral (Madrid, España). Cidaris, 30, 151-153.

Hernández-Ballarín, V., Oliver, A. \& Peláez-Campomanes, P. 2011. Revisión de las asociaciones de mamíferos del tránsito Aragoniense medio y superior de la Cuenca de Madrid. In: Viajando a Mundos Pretéritos (eds. PérezGarcía, A., Gascó, F., Gasulla, J.M. \& Escaso, F.). Ayuntamiento de Morella, Castellón, España, 173-182.

Herráez, E. 1993. Micromamíferos (roedores y lagomorfos) del Mioceno del área de Madrid: estudio sistemático y bioestratigráfico. PhD Thesis, Universidad Complutense de Madrid (unpublished).

López Guerrero, P., Oliver Pérez, A., Álvarez Sierra, M.A., García Paredes, I., Van den Hoek Ostende, L.W. \& PeláezCampomanes, P. 2007. Paleontología del yacimiento de vertebrados Aragoniense de Casa Montero (Madrid). In: Cantera Paleontológica (eds. Cambra-Moo, O., MartínezPérez, C., Chamero, B., Escaso, F., de Esteban Trivigno, S. \& Marugán-Lobón, J.). Diputación Provincial de Cuenca, Castilla La Mancha, 247-254.

López-Martínez, N. (ed.) 1989. Revisión sistemática y bioestratigráfica de los Lagomorpha (Mammalia) del Terciario y Cuaternario inferior de España. Memorias del Museo Paleontológico de Zaragoza, Universidad de Zaragoza, Zaragoza.

López-Martínez, N., Élez Villar, J., Hernando, J.M., Luís, A., Mazo, A., Mínguez Gandú, D., Morales, J., Polonio, I., Salesa, M.J. \& Sánchez, I. 2000. Los fósiles de vertebrados de Somosaguas (Pozuelo, Madrid). Coloquios de Paleontología, 51, 69-86.

López-Martínez, N., Peláez-Campomanes, P. \& Hernández Fernández, M. (eds.). Homage to late Dr. Remmert Daams. Coloquios de Paleontología Spec. Vol. 1, 281-310.

Luís, A. \& Hernando, J.M. 2000. Los microvertebrados del Mioceno Medio de Somosaguas Sur (Pozuelo de Alarcón, Madrid, España). Coloquios de Paleontología, 51, 87-136.
Megías, A.G., Ordóñez, S. \& Calvo, J.P. 1983. Nuevas aportaciones al conocimiento geológico de la Cuenca de Madrid. Revista de Materiales y Procesos Geológicos, 1, 163-191.

Menéndez Gamella, A., Serrano, H., Presumido, M., Cárdaba, J.A. \& Fesharaki, O. 2010. Yacimientos paleontológicos de Húmera (Mioceno medio, Cuenca de Madrid): Datos preliminares en Estratigrafía y Paleontología. Cidaris, 30, 187-196.

Peláez-Campomanes, P., Morales, J., Álvarez Sierra, M.A., Azanza, B., Fraile, S., García Paredes, I., Hernández Fernández, M., Herráez, E., Nieto, M., Pérez, B., Quiralte, V., Salesa, M.J., Sánchez, I.M. \& Soria, D. 2003. Updated biochronology of the Miocene mammals fauna from the Madrid basin (Spain). Deinsea, 10, 431-441.

Soria, D., Amezúa, L., Daams, R., Fraile, S., Herráez, E., Morales, J., Nieto, M., Peláez-Campomanes, P., Salesa, J.M. \& Sánchez, I.M. 2000. Faunas del Mioceno. In: Patrimonio paleontológico de la Comunidad de Madrid (eds. Morales, J. Nieto, M. Amezua, L. Fraile, S. Gómez, E. Herráez, E. Peláez-Campomanes, P. Salesa, M.J. Sánchez, I.M. \& Soria, D.). Consejería de Educación de la Comunidad de Madrid, España, 111-129.

Torres, T., Maldonado, A., Querol, R. \& Zamora, I. 1995. Evolución en el subsuelo de los sistemas de abanicos aluviales del Mioceno de la cuenca de Madrid (España). Geogaceta, 18, 56-58.

Van Dam, J.A., Abdul Aziz, H., Álvarez Sierra, M.A., Hilge, F.J., Van den Hoek Ostende, L.W., Lourens, L.J., Mein, P., van der Meulen, A.J. \& Peláez-Campomanes, P. 2006. Long-period astronomical forcing of mammal turnover. Nature, 443, 687-691.

Van den Hoek Ostende, L.W. 2001. A revised generic classification of the Galericini (Insectivora, Mammalia) with some remarks on their palaeobiogeography and phylogeny. Geobios, 34 (6), 681-695.

Van den Hoek Ostende, L.W. 2003. Insectivores (Erinaceomorpha, Soricomorpha, Mammalia) from the Ramblian of the Daroca-Calamocha area. In: En torno a Fósiles de Mamíferos: Datación, Evolución y Paleoambiente. (eds. López-Martínez, N. PeláezCampomanes, P. \& Hernández Fernández, M.). Coloquios de Paleontología, vol. Ext. 1, 281-310.

Van der Meulen, A.J., Peláez-Campomanes, P. \& Daams, R. 2003. Revision of medium-sized Cricetidae from the Miocene of the Daroca-Villafeliche area in the Calatayud-Teruel basin (Zaragoza, Spain). Coloquios de Paleontología, vol. Ext. 1, 285-441. 